\title{
The Role of Values-Based Leadership within the Framework of Values Shifting Appearing in Indonesian Education
}

\author{
Rita Anggorowati \\ Educational Department \\ School of Post Graduates UPI \\ Bandung, Indonesia \\ ritalope11@student.upi.edu
}

\begin{abstract}
Shifting values that appear in the Indonesian education is inevitable. They are due to changes that occur in the life of the nation as a result of the progress and changes in the climates of politics, economics, social, and cultural. The leader position, in facing the existing anomie challenges, plays a very important role. To eliminate anomie and make full cultural values, a leader needs to establish basic values and behavioral patterns that determine the right mindset. In this paper, two research results, regarding the influence of values-based leadership on the shifting of values in education both philosophically and practically, will be presented. Subjects in both studies above was taken in two different areas; Sumedang regency, West Java and East Halmahera, Maluku. In addition to differences in study subjects, the spans of the research implementation were also different. This part can be seen as the representation of the condition of how values-based leadership providing roles in shifting of values in the Indonesian education. Both studies produce data that show the values-based leadership has proven to bring positive work culture that encourages the advancement of organization (in this case the schools). Primarily, they are determined by personal values of principal as leader.
\end{abstract}

Keywords - values-based leadership: values shifting: indonesian education

\section{INTRODUCTION}

"The only thing that work is management by values. Find people who are competent and really bright, but more importantly, people who care exactly about the same things you care about.' - Steve Jobs, Co-Founder, Apple Inc, 1955 2011.

"You must be the change you wish to see in the world." Mahatma Gandhi, 1896 - 1948.

Shifting values that appear in the Indonesian education is inevitable. They are due to changes that occur in the life of the nation as a result of the progress and changes in the climates of politics, economics, social, and cultural. [1]

"Today, like it or not and want it or not, the people of Indonesia have to live and be in the vortex of globalization of the world. However, the national identity must still be maintained. Therefore, various changes should be regarded as the nation's efforts to develop its own personality through an adjustment to the demands and the needs of modern society.
By its own personality, the people of Indonesia must be brave and able to meet and to look at the world. In a world that is increasingly global, the people of Indonesia are to not only absorb the influx of capital, technology, knowledge, and skills, but also be brought to enter social and political values that are derived from other cultures. To that end, the most important thing is how the people of Indonesia is capable to filter. As a result, only the good and suitable cultural values are absorbed."

\section{LITERATURE REVIEW}

The diversity that occurs in the ordinary life, whether it is in the smallest unit in a form of families or in the largest unit in a form of the world, can never be separated from various differences; gender, tribe, religion, race and groups. Indonesia, as a big nation with enormous type of diversity, nowadays is having a situation of paradigm shifted as a result of globalization. The massive influx coming from different cultures and values started to make Indonesia entering the phase [2] described as a condition where organizations in this country are losing ground; they have become less competitive, less effective, and less rewarding to its members. Individuals have an increased sense of alienation, isolation, and mistrust, with a corresponding decreased sense of self-confidence, selfworth, satisfaction, and security.

What had happened in Indonesia then shows that the society is falling into a bad condition, with acceleration in crimes, deterioration in educational system and disintegration of families on a daily basis.

The critical condition faced by Indonesia is often referred to as anomie. Reference [2] contains the definition of anomie as, "(1) The lack of purpose, identity, or values in a person or in a society - disorganization, detachment, or rootlessness. (2) Normlessness - condition of society characterized by a breakdown of norms that rule the conduct of people and assures the social order. (3) Personal unrest, alienation, and uncertainty that comes from a lack of purpose or ideas.'

Briefly, anomie can be interpreted as a critical condition in an organization because of social change where the old norms/values are faded; at the same time, the new norms/values that will replace have not yet formed. Anomie is also meant alienation Kuczmarski, Susan Smith. \& Kuczmarski, Thomas D, or estrangement. This situation is a 
result of eroded or loss of values and norms on individuals and groups.

The figure below is a picture of the Anomic Dilema to describe the details of anomie that occurs in the conditions of lack of norms and values and ineffective leadership that are a bad influence to the performance and the competitiveness of the organization.

Fig. 1. Dilemma Anomic

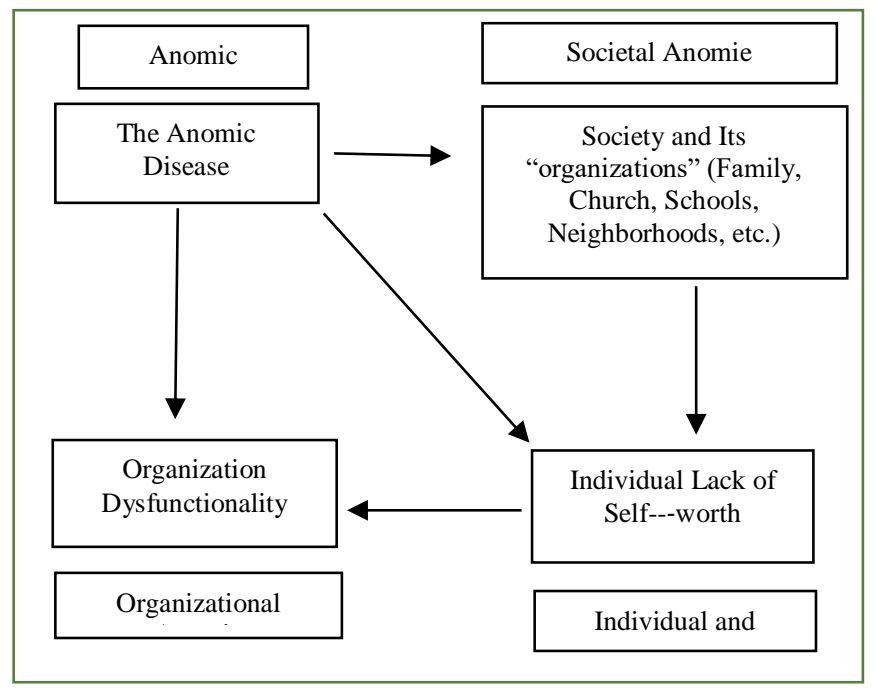

Source: Kuczmarski \& Kuczmarski (1995, p. 7).

Reference [3] defines value as beliefs about what is right and wrong and what is important in life; and norms as standards of behavior that are typical of or accepted within a particular group or society.

Furthermore, Kuczmarski, Susan Smith. \& Kuczmarski, Thomas D points out the relationship between values and norms, as follows.

"Values are the shared goals, beliefs, ideals, and purposes of the group. Values often evoke inner convictions among group members. But, in order for a group to maintain a set of values, the group must establish norms that shape and influence the behaviors, attitudes, and activities of its members. Norms are expected behaviors by members of a group; they are groupdecided codes of conduct. A norm is a standard to guide group behavior. It is a predisposition or an attitude on the part of a group to think, feel, and act in a particular way."

The leader position, in facing the existing anomie challenges, plays a very important role. Reference Kuczmarski, Susan Smith. \& Kuczmarski, Thomas D suggests that to eliminate anomie and make full cultural values, a leader needs to establish basic values and behavioral patterns that determine the right mindset.

There should be a leader with the right leadership patterns and able to bring positive changes while working together in the organization. Reference Kraemer, Harry M. Jansen

States that "Leadership is not about the leader. Leadership is about the growth and positive change that a leader can bring about while working with others."

Furthermore, reference [5] says that a good leader is a leader who can build shared values and norms among his/her followers. Important value in an organization is a reference of movement of all members of the organization toward the achievement of objectives.

Based on the foregoing, this paper is made in order to see the role of value-based leadership within the framework of shifting of values that appear in the Indonesian education, in both philosophical and practical aspects.

\section{A. Definitions, Principles, Fundamental Elements of Values- Based Leadership}

Values-based leadership was defined as a relationship between a leader and followers based on ideological values that are believed and infused strongly together. Kuczmarski, Susan Smith. \& Kuczmarski, Thomas D "The underlying principle for developing a values-based mindset is relationship building." In other words, the main principle for building a values-based mindset is to build good relationships. A leader needs to relate effectively with all members of the organization, to establish value-based sample through words and actions, and to achieve success in building meaningful relationships within the organization. The main concept is, "Leaders must lead the values."

Building a good relationship is not an easy job. [6] [7] [8] [9] In fact, it is the most important role in the organization, given the leadership can develop when individuals interact each other in the group, with the condition personal relationships have been formed and the trust have been built.

In order to build an effective relationship, a leader needs to cultivate following characteristics and attributes:

- Listen actively.

- Empathetic.

- Attitudes are positive and optimistic.

- Delivers on promises \& commitments.

- Energy level is high.

- Recognizes self-doubts and vulnerabilities.

- Sensitivity to other's needs, values, and potential.

It is very interesting to pay attention on the LEADERS attributes above. The attributes are the foundation of valuesbased leadership and are very useful in developing interpersonal relationships.

Leadership needs frequent training and practice because improving the quality of leadership is a continuous and neverending process. None of the leaders achieves perfect success in leadership sharpness and effectiveness. Reference Kuczmarski, Susan Smith. \& Kuczmarski, Thomas D proposes ten initiatives, which need to be developed by all value-based leaders, as shown in the following figure.

Fig. 2. Ten Initiatives to be Developed by all Value-Based Leader

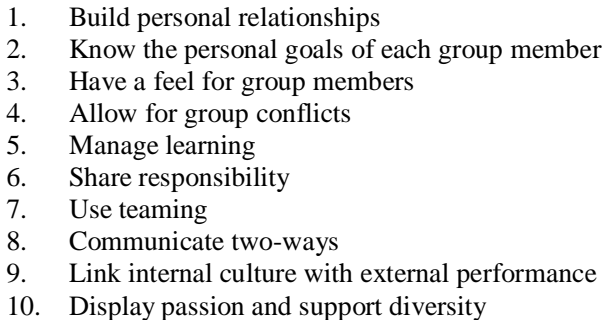




\section{1) Build personal relationships}

First proposed initiative is to build personal relationships. This process requires effort, time, and action. When we have developed a strong relationship, we will work more effectively together, better understand one another, and be able to struggle more effective in the job. There are three steps in building personal relationships:

- Desire (passion) - The desire have to be seen clearly and felt by others. An effective leader expresses a desire or intention through speech, action, and a genuine emotional to know others better. One of the easiest ways to accomplish this is by expressing the wishes verbally, spend some time with other people and ask them personal questions.

- Time - Building a relationship is impossible to be done in a short time. A leader needs to spend some time with someone in three ways: (1) work together, (2) further socialize in the outside of work context, and (3) often interact and practice both previous ways consistently. Take the time in terms of work to explain something in more detail; help group members to confront problems; take time to try to better understand why a member of the group is always delay the work; listening purposes on projects made by group members. Furthermore, leader can take some time in the event of non-work. It is more inclined to social life, where the conversations will be more personal to strengthen the relationship.

- Action - Some actions can be performed in relationships. They can be in the form of exchanging letters, notes, or short memo that praised performance, expressing recognition, or praise verbally, say hello to each other, or invitation to join in an activity. One thing to keep in mind, fostering personal relationships is the responsibility of all members of the group and the leader. This is essential in a values-based leadership.

\section{2) Know the personal goals of each group member}

A group or a team has a set of goals or personal member goals in almost the entire group task or job. A leader, in particular, needs to find and understand personal goals in order to help each individual to achieve them. The personal goals can be used as a platform to build the group's goals. It is an interesting process where leaders must understand the needs of group members and help them. Then, they can define new needs and connect them with the requirements of the group. In other words, an effective leader should be sensitive to the needs and goals of individuals and members of the group. Leader is responsible for coordinating and monitoring this dynamic process, where the members are also responsible to articulate their needs clearly.

\section{3) Have a feel for group members}

The key of leadership effectiveness is to have a sense on each member of the group, where the latter, in return, they will feel the same on the leader. Every leader should focus on the strengths and weaknesses of its members. Leaders need to determine exactly how to motivate members and what actions that can disappoint members of the group.

\section{4) Allow for group conflicts}

Acquiring leadership occurs when individuals relate each other in the group. Conflict is a part of these interactive activities. In addition, this is normal. An effective leader knows how to deal with conflicts in the group. Leader needs to allow group to experience conflict because the conflict itself can be a catalyst for members of the group to be parts of and to contribute by resolving the situation. Conflicts can form a group member leadership. Leadership practices can be practiced in overcoming conflict.

\section{5) Manage learning}

Leader needs to act as manager of learning and act as a Socratic teacher. Managing-learning process requires leader to gather information from learners, making learners involved, following the learning, and realizing their progress during the learning process is over. The three levels in this process are Discovery (find previous knowledge), Teaching (including hearing, seeing, experiencing, writing and performing), and Application (to apply).

\section{6) Share responsibility}

When organization begins to build a culture of full value, the performance of employees will change to the division of responsibilities and no longer focus on success or failure of individuals. Everybody wants to play an active role and system of responsibility, no longer simply a top-down direction.

\section{7) Use teaming}

Effective leaders will maximize group function maximally. Working in-group will provide greater opportunities for an individual to practice leadership skills and behaviors. They will be able to maintain and to build a culture of the group and a sense of the community by sharing values.

\section{8) Communicate two-ways}

Two-way communication is a key in building a value-based culture and implements cultural changes. A good communication is essential in supporting the process of developing a vision and values that can help to realize that vision.

\section{9) Link internal culture with external performance}

Satisfaction in the internal culture will affect the external performance of an organization. If an organization has built and focused on norms and values internally, the group members will feel much more proud of and feel positive towards the organization. Individual performance will increase, and it affects the performance of the organization.

\section{0) Display passion and support diversity}

Values-based leader will always feel safe with self and comfortable in expressing emotions. They can communicate their feelings, are open to members of group. Therefore, positive praise, neutral dialogue, or constructive criticism can be delivered clearly. Strong understanding of differences and supporting pluralism provide opportunities for a leadership that legitimizes value and respects every individual in organization.

For additional reference, Kraemer, Harry M. Jansen revealed four principles in values-based leadership below. 
Fig. 3. 4 Principles of Values-Based Leadership

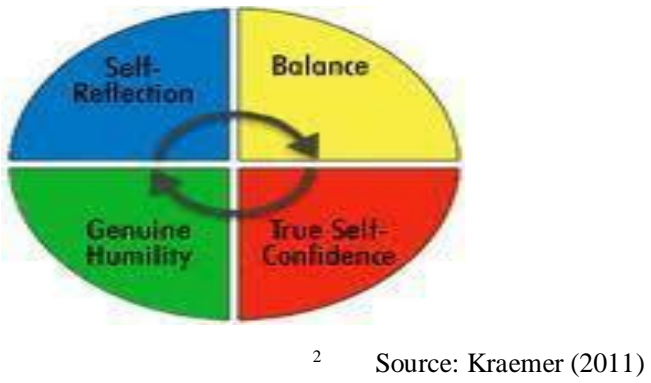

In the dynamic world for leaders around the world, Kraemer, Harry M. Jansen shows that the journey to be a value-based leader is based on four basic principles. They can guide leaders to make choice that is consistent with their values. The four important principles he states in his book From Values to Action are as follow.

\section{a) Self-Reflection}

This is an ability to step back and to reflect, to filter out the noise and distractions, to identify what you stand for, what your values are, and what is most important. With reflection, you can prioritize how and where to invest time and effort and to make easier choices that reflect your values.

\section{b) Balance}

This is an ability to see things from different perspectives, including different viewpoints, to gain a more holistic understanding. Balance enable you to make the decision by appreciating a broader impact, instead of focusing narrowly.

\section{c) True Self-Confidence}

This is the inner qualities that define your leadership and allows you to empower your team. Far more than just competence in your job or the mastery of certain skills, true self-confidence allows you to see and to accept yourself, identifies your strengths and weaknesses, with a commitment to continuously improvement as a learner.

\section{d) Genuine Humility}

The ability to never forget who you are, to appreciate the value of every person in the organization, and to treat everyone with respect no matter whether they are senior managers or children who do a paid internship during the summer. Sincere humility allows you to be authentic, approachable, and open to others based on who you really are.

The four principles are interrelated and depend on each other. Each component builds and contributes. Taken together, these four principles build a strong foundation on the application of values-based leadership.

At first glance, the four principles of values-based leadership looks simple, but they actually are not that easy to implement. The four principles represent a long-term discipline that will challenge us to continue to proceed and take us on what is most important in the organization.
According to reference Kraemer, Harry M. Jansen for any small organization we lead, there are six fundamental elements in value-based organization:

- Leading with values;

- Leadership development and talent management;

- Setting a clear direction for the organization;

- Effective communication;

- Motivation and team engagement; and

- Execution and implementation.

In charge of a value-based organization, Kraemer, Harry M. Jansen explains the following steps that need to be done by an effective leader.

- Lead with courage in times of change and crisis in which controversy arises. At this time, a leader is not only expected to have been prepared but is also expected to perform optimally as when leading at times of normal circumstances.

- Leaders must be able to shift their focus from mere success towards giving meaning. Leaders are expected not only to care for himself and his organization, because values-based leader acts to provide a positive influence on the world, not only in terms of their organization.

- Leader should be able to put their personal priority under other interests, such as interests of groups, customers, consumers, and suppliers, as well as acts to be someone who is responsible to the social environment.

\section{DISCUSSION}

An effective school leader and manager are needed in both the developed and developing countries, such as Indonesia. Currently, its administration wants to provide the best education for students and learners. This is consistent with the view of [10] "In many parts of the world, including both developed and developing countries, there is recognition that schools require effective leaders and managers if they are to provide the best possible education for their students and learners.“

As mentioned in the Introduction, shifting of values that appears in Indonesian education is inevitable as the changes that occur in the life of the nation because of the progress and changes in the climates of politics, economics, social, and cultural. As an effect of this shifting of values, the role of a leader, especially the leader of education (teachers and principals), is very important, especially in facing anomie challenges that have been shown previously.

In this part, two research results, regarding the influence of values-based leadership on the shifting of values in education both philosophically and practically, will be presented. Both studies examine the role of the application of values-based leadership. 
Both of these studies produce data that shows the results in the following paragraphs. Suryana, Asep in his thesis research concludes that school leadership should be supported by good personal values. It is proved that, on average $(51.5 \%)$, principals agree that several values should exist within the school principal. The values are the honest values of words and deeds received a state of self, self-control, adjustment to the environment, treatment of the self, attitude towards work, the desire to go forward, demonstrate the ability, packing hope, adept at communicating, the symbol of good self, selfevaluation, obedient but in harmony, and not easily give up.

Furthermore, he concludes that values of a person in the organization must be derived from the values of the organization, where the values of the organization became the starting point in carrying out its work. When the personal values still survive in ideal conditions personally, then that will bring contradictions between demands of organization in achieving its objectives with roles of individuals in their values. Held personal values will be a big appearance in work behaviors than values of organization that should be its reference. As a social system, organization calls for the same behavior that emerges from its members.

Meanwhile, the results of research by [11], especially in the section dealing with values-based conclude the following:

- Values-Based Leadership of Principal is a leadership that reflects the moral basis underlying management decisions and actions on a broad reference to the basic principles or core values such as honesty, fairness, sincere attitude, confidence, integrity, and exemplary discipline and social responsibility, commitment, and effective at work. They assign functions of relationships by putting the values in into practices and functions of leader to bring the values into the relationship.

- Value-Based Leadership of Principal has contributed significantly to the strong productivity category against the school. Thus, the value-based leadership principals that are implemented increase the productivity of schools, through the leadership, which refers extensively on leadership based on values. The values include or even part of a philosophy of life that is believed and putting values such as honesty, fairness, sincere attitude, confidence exemplary, discipline, commitment and effectiveness in practice, and embodied in the act of leadership.

- Values-Based Leadership of Principal and the school organizational climate jointly contribute positively to the productivity of school. Therefore, these two factors have contributed to increase productivity of school. However, to increase the productivity of school, many other factors may affect such the cost of education, the professionalism of teachers, curriculum, educational supervision, and so forth.

The subjects in both studies above were taken in two different areas. The subjects of study Suryana, Asep were the principals of vocational schools in Sumedang regency, West Java. In [11], the subjects of research are the principals of State Junior High Schools in East Halmahera, Maluku. In addition to differences in study subjects, the spans of the research implementation were also different. This part can be seen as the representation of the condition of how values-based leadership providing roles in shifting of values in the Indonesian education.

Both studies produce data that show the values-based leadership has proven to bring positive work culture that encourages the advancement of organization (in this case the schools). Primarily, they are determined by personal values of principal as leader.

\section{CONCLUSION}

Referring to both research results presented above, it is clear that the value-based leadership has a positive role in facing the shifting of values and anomie that occurred in the Indonesian education system, both philosophical and practical. [12]

The opinion of experts and researchers, both at home and abroad, equally indicate a positive trend in the application of values-based leadership model in facing future changes. [13] and [14].

Philosophically and practically, the essence of this valuebased leadership is that 'Diversity is a gift'. It depends upon the value of 'taste' in processing differences to be a meaningful value, which to support each element, thus encourage the organization's progress on the goals, perhaps even more.

The main concept of value-based leadership is, "Leaders must lead the values." An important note of this concept is how personal value of a leader is a proof of leadership itself. How a leader has a thought, produce words orally, act in the form of action, need to reflect the value that is either propriety or regulation reflects the values promoted. This value will later form the culture of organization and determine how organization is run.

In relation to the shifting of values in Indonesian education, change is inevitable in the process. Then the agents of change, as Gandhi's quote at the beginning of this paper, are effective leaders, values-based leaders who are ready to make changes meaningful changes.

\section{REFERENCE}

[1] Lemhanas RI. (2012). Memperkokoh Nilai-Nilai Pancasila di Seluruh Komponen Bangsa untuk Memantapkan Semangat Kebangsaan dan Jiwa Nasionalisme Ke-Indonesia-an dalam Rangka Menangkal Ideologi Radikalisme Global. Jurnal Kajian Lemhanas RI, Edisi 14. [Online] Cited from: http://www.lemhannas.go.id/portal/images/stories/humas/jurnal/jurnal_i nternasional3.pdf

[2] Kuczmarski, Susan Smith. \& Kuczmarski, Thomas D. (1995) ValuesBased Leadership. Prentice Hall, Inc. Eaglewood Cliffs, NJ.

[3] Hornby, A.S. (2000). Oxford Advanced Learner's Dictionary 6th Edition. Oxford University Press. Great Clarendon Street, Oxford OX26DP, Oxford.

[4] Kraemer, Harry M. Jansen. (2011). From Values to Action: The Four Principles of Values-Based Leadership. Jossey-Bass, A Wiley Imprint. 989 Market Street, San Fransisco, CA.

[5] Suryana, Asep. (2010). Kepemimpinan Berbasis Nilai (Value-Based Leadership) Dalam Pencapaian Tujuan Organisasi Melalui Budaya Kerja : Studi Tentang Pengaruh Kepemimpinan Berbasis Nilai; Nilai-Nilai Personal Dan Komitmen Dalam Pencapaian Tujuan Organisasi Melalui 
Budaya Kerja;Sikap Kerja, Disiplin Kerja, Kualitas Kerja, Dan Hubungan Kerja Di Sekolah Menengah Kejuruan. S3 Thesis, Universitas Pendidikan Indonesia. [Online] Cited from: http://repository.upi.edu/7555/

[6] Aaker, David A. [2012). Building Strong Brands. The Free Press, A Division of Simon \& Schuster Inc. 1230 Avenue of the Americas, New York, N.Y. 10020

[7] Covey, Stephen R. (2014). The 7 Habits of Highly Effective Families; Buildimg a Beautiful Family Culture in a Turbulent World. Franklin Covey, St. Martin's Griffin 888 Seventh Avenue, New York, NY 10106.

[8] Fullan, Michael. (2014). Leading in a Culture of Change: Personal Action Guide and Workbook. Jossey-Bass A Wiley Imprint, 989 Market Street, San Fransisco, CA 94103-1741.

[9] Osterman, Paul. (2008). The Truth About Middle Managers: Who They Are, How They Work, Why They Matter. Harvard Business Press, Boston: Massachusetts.

[10] Bush, Tony. (2008). Leadership and Management Development in Education. SAGE Publications Ltd. 1 Oliver's Yard 55 City Road, London.

[11] Amir, Muhtar. (2012). Kontribusi Kepemimpinan Berbasis Nilai (ValueBased Leadership) Kepala Sekolah Dan Iklim Organisasi Sekolah Terhadap Produktivitas Sekolah Pada Smp Negeri Di Kabupaten Halmahera Timur. S2 Thesis, Universitas Pendidikan Indonesia. [Online] Cited in http://repository.upi.edu/7952/

[12] Lehnert, Kevin., Craft, Jana., Singh, Nitish., \& Park, Yung-Hwal. [2016]. The Human Experience of Ethics: a Review of a Decade of Qualitative Ethical Decision-Making Research. Business Ethics, a European Review Volume 25, issue 4 October 2016 [pp. 498 - 537]. [Online] downloaded from: http://onlinelibrary.wiley.com/doi/10.1111/beer.12129/full

[13] Dinh, Jessica E., Lord, Robert G., Gardner, William L, Meuser, Jeremy D, Liden, Robert C., \& Hu, Jinyu. (2014). Leadership Theory and Research in the New Millennium: Current Theoritical Trends and Changing Perspectives. ELSEVIER The Leardership Quarterly Volume 25, Issue 1, February 2014 [pp. 36 - 62]. [Online] downloaded from: http://www.sciencedirect.com/science/article/pii/S1048984313001203.

[14] Johnson, McKinley. (2016). Values-centered Leadership: A Biblical Worldview for Understanding the Driving Forces Behind Individual and Organizational Behavior. Creation House: A Charisma Media Company, 600 Rinehart Road, Lake Mary, Florida 32746. 